\title{
Pathogenic Fungi: an unacknowledged risk at coastal resorts? New insights on microbiological sand quality in Portugal
}

Raquel Sabino ${ }^{a}$, Filipa C Ferreira ${ }^{a}$, Cristina Veríssimoa ${ }^{a}$ Maria Ana Cunha ${ }^{b}$, Bela Wergikoski ${ }^{b}$, Eleonora Paixão ${ }^{a}$, Filipa Ferreira ${ }^{a}$, Raquel Rodrigues ${ }^{a}$, Helena Parada ${ }^{a}$, Leonor Falcão ${ }^{a}$, Laura Rosado $^{\mathrm{a}}$, Catarina Pinheiro ${ }^{\mathrm{a}}$, Eleonora Paixão ${ }^{\mathrm{a},}$ João Brandão ${ }^{\mathrm{a}}$

${ }^{a}$ National Institute of Health Dr. Ricardo Jorge, Av. Padre Cruz 1619-016 Lisboa, Portugal.

${ }^{\mathrm{b}}$ Portuguese Environmental Agency, Apartado 7585, 2611-865 Amadora

*Corresponding author. Tel:(+351)217519247; Fax: (+351)217526400

Email: joao.brandao@insa.min-saude.pt

\section{ABSTRACT}

Whilst the potential impact on beach users from microorganisms in water has received considerable attention, there has been relatively little investigation into microbial contaminants in sand. 33 beaches across Portugal were analyzed during a five year period (2006-2010) to determine the presence of yeasts, pathogenic fungi, dermatophytes, total coliforms, E. coli and intestinal enterococci in sand.

Our results showed that $60.4 \%$ of the samples were positive for fungi and that $25.2 \%$ were positive for the bacterial parameters. The most frequent fungal species found were Candida sp. and Aspergillus sp., whereas intestinal enterococci were the most frequently isolated bacteria. Positive associations were detected among analyzed parameters and country-regions but none among those parameters and sampling period.

Regarding threshold values, we propose $15 \mathrm{cfu} / \mathrm{g}$ for yeasts, $17 \mathrm{cfu} / \mathrm{g}$ for potential pathogenic fungi, $8 \mathrm{cfu} / \mathrm{g}$ for dermatophytes. $84 \mathrm{cfu} / \mathrm{g}$ for coliforms, $250 \mathrm{cfu} / \mathrm{g}$ for $E$. coli, and $100 \mathrm{cfu} / \mathrm{g}$ for intestinal enterococci

\section{Highlights:}

- $60.4 \%$ of the analyzed marine beach sand samples were positive for the studied fungi

- Candida sp. and Aspergillus sp. were the most frequent fungal species found

- $25.2 \%$ of the analyzed marine beach sand samples were positive to the studied bacteria 
- Positive association was found between the presence of yeasts and coliforms

- Proposal of microbiological threshold values for marine beach sands

Keywords: Sand Quality, Beach, Fungi, Bacteria, Bioindicators, Microbiological Thresholds

\section{Introduction}

Beaches, both coastal and inland, are amongst the most significant sites for water based recreation. Bathing, contact waters sports and appreciation of the general ambience are all valuable uses made of these areas. The importance of good water quality, particularly microbiological quality is reflected in the statutory limits now in place in most of the developed world. The influence of water quality on bathers' health was extensively reviewed by the World Health Organisation (WHO, 2003). The European Community Bathing Water Directive (2006) places greater emphasis on measures for the protection of the (bathing) public. Development of quality of life and health of the population is a complex function of different conditions of the living environment. Exposure to organic and inorganic pollutants as well as to the wide spectrum of microorganisms is part of this problem (Matavulj et al., 2005). Potentially pathogenic microorganisms in sands include faecal bacteria as found in the water but also mycological agents including fungi, yeasts and moulds (Vieira et al., 2001; Mancini et al., 2004; Abdallah et al., 2005; Sato et al., 2005; Gomes et al., 2007). Several American (Vieira et al., 2001; Sato et al., 2005; Gomes et al., 2007) and European studies (Brandão et al., 2002; Mancini et al., 2004; Abdallah et al., 2005; Matavulj et al., 2005) have been performed on this issue and although the World Health Organisation report considered sand contamination it made no recommendations as to standards, neither do they feature in current European or US legislation.

With this emphasis on public protection, it is perhaps surprising that there have been no similar bacterial or mycological limits for sand, though more beach users come into contact with the sand than the water. Bathers and those engaged in water sports will invariably also be in contact with the sand, yet there are many beach-goers who never enter the water (LaLiberte and Grimes, 1982; Obiri and Jones, 2000; Alm et al. 2003; Whitman, 2006). 
To date, no correlation has been shown between health and pathogenic fungi in beach sands

(Prado et al., 1994; Brandão et al., 2002) but it may be expected that the public exposed to sand contaminated with fungal pathogens are at an increased exposure risk through direct contact with their skin and mucous membranes or by inhaling spores. Beach users, both people and animals, may themselves be partially responsible for contaminating beach sands, either by carrying microorganisms that are left on the sand or by discarding organic litter, including refuse from fishing, which provides the food and humidity necessary for the preservation and development of yeasts, bacteria, and moulds (Brandão et al., 2002). Recently Heaney et al., 2009, performed an epidemiological study on beach users and observed strong association between sand contact and enteric illness at marine beaches.

The Blue Flag scheme (FEE) is one of the principal mechanisms for the maintenance of beach quality standards and it currently monitors 29 different indicators which cover Environmental Education and Information, Water Quality, Environmental Management, Safety and Services (Associação Bandeira Azul da Europa, 2009). One matter insufficiently addressed to date is whether contact with beach sand should be of concern to public safety. In order to address this concern, a project was created within Portugal, as a joint venture between the Portuguese Blue Flag Association, the National Institute of Health and the Environmental Protection Agency. The present work reports on the microbiological quality of the sand at selected beaches, including the distribution of bacteria and fungi collected from beach sands and suggest threshold values for selected microbiological indicators.

\section{MATERIALS AND METHODS}

\section{Study Design}

The Portuguese coast was divided into five regions (North, Central, Lisbon and Tagus Valley, Alentejo and Algarve) and a total of 164 different sand beaches were analyzed during the period 2006-2010. All the selected beaches are classified as good quality beaches, holding the Blue Flag award. Thirty three were analyzed every year during the referred sampling period and those were the ones selected for the present study. From the 33 beaches, four were from the North, four from the Central, nine from Lisbon and Tagus Valley (LVT), one from Alentejo and 15 from Algarve. Three sand samples were collected from each beach during the summer season (June, July and August).

\section{Sample collection}

Samples were collected at a depth of about $10 \mathrm{~cm}$, with sterile gloves into a sterile plastic container, from the middle of the dry sand section of the shore, as three equidistant sub-samples which mixed into one composite, represented each beach as a whole. The first sampling event took place at start of the bathing season, the second in the peak of the summer (highest concentration of users), and the last before the end of the bathing season. Samples were processed within 18 hours and transported refrigerated to the laboratory. 


\section{Sample analysis \\ Mycological}

Each sand sample (40 g - not oven-dried prior to processing, retaining thus it's natural water content), was diluted in $40 \mathrm{~mL}$ of sterilized distilled water, agitated for 30 min at $100 \mathrm{rpm}$ and $0.2 \mathrm{~mL}$ of this suspension was spread, in triplicate, onto Petri dishes containing Mycobiotic agar for dermatophytes (up to 3 weeks incubation at $\left.27.5^{\circ} \mathrm{C}\right)$ and malt extract agar $(2 \%)$ with cloramphenicol $(0.05 \mathrm{~g} / \mathrm{L})$ for non-dermatophyte fungi (5-7 days at $27.5^{\circ} \mathrm{C}$ of incubation). Fungal identification was carried out by macroscopic and microscopic (using lactophenol blue staining) observation of colonies for filamentous fungi, using identification atlases and using the biochemical identification galleries ID32C (bioMérieux SA, Marcy-l'Etoile, France) for yeasts. Results were reported as the average count of the three replicas, in colony forming unit per gram of sand (c.f.u/g) when detecting the fungal species more frequently associated to human infections, as indicated in Table I. Other moulds are reported when being the predominant species, or with extremely high counts over 500 colony forming unit per gram of sand (cfu/g). Histoplasma spp., Coccidioides spp., Exophiala sp., Fonsecae spp., Phialophora spp. were always reported. This methodology is accredited by the ISO17025 (IPAC L0425).

\section{Bacteriological}

Detection of total coliforms/Escherichia coli (E. coli) and enterococci was accomplished through the use of Colilert and Enterolert with Quanti-Tray (IDEXX Laboratories, Maine, USA) respectively. Extraction fluid resulting from $50 \mathrm{~g}$ of sand extracted with $500 \mathrm{ml}$ of sterile distilled water and agitating for $30 \mathrm{~min}$ at 100 rpm was processed according to manufacturer's instructions, both for Colilert and Enterolert and for each sample. Bacteria detected and reported individually, as indicated in Table 1. The methods complied with HPA NHS W18 and ASTM D6503-99 respectively.

\section{Statistical analyses}

Descriptive analysis for parameters was performed, using means, 95\% confidence intervals for mean, median, minimum and maximum values for continuous variables. Counts and percentages are categorical variables. Pearson correlation coefficient was used to measure the association between parameters. The Mean values of parameters were compared between years, months and regions of samplings using ANOVA. The Brown-Forsythe robust tests of equality of means were used to fortify the results of ANOVA when the variances of groups were significantly different. Fisher's Least Significant Difference (LSD) or the Dunnet post hoc tests for multiple comparisons were used assuming homogeneity of variances or not, respectively. $90,95,97.5$ and 99 percentiles were calculated to establish thresholds for the parameters, using the distributions of values for the five years of sampling. Values of $p \leq 0.05$ were accepted as statistically significant. IBM SPSS version 18.0 software was used to perform all statistical analysis.

\section{Results}

During a five year period 33 beaches distributed along the Portuguese coast (Figure 1) were analyzed. A total of 495 sand samples were collected and processed in mycological and bacteriological laboratories.

From the 495 analyzed sand samples, 299 (60.4\%) were positive for the investigated fungal species and 125 samples (25.2\%) were positive for the three bacterial groups analyzed. One hundred and sixty five samples (33.3\%) were negative for all the parameters analyzed whereas $100(20.2 \%)$ of them were positive for both parameters (Table 2).

The number of fungal colony-forming units of yeasts and dermatophytes tends to increase along the sampling periods, whereas the bacterial number of colony forming units tends to decrease from the first to the second sampling period and is maintained from the second to the third one (Figure 2). Nevertheless, no positive association was found between the the three sampling periods in yeasts $(p=0.321)$, potential pathogenic fungi $(p=0.056)$, dermatophytes 
$(p=0.171)$, coliforms $(p=0.976)$, E. coli $(p=0.90)$, and intestinal enterococci $(p=0.332)$. Concerning the distribution of the number of fungal colony-forming units along the Portuguese coast (Table 3), the highest value was observed in beaches belonging to the Central region of Portugal (average of $498.9 \mathrm{cfu} / \mathrm{g}$ ) whereas the lowest values were detected in beaches from Algarve (average of $62.5 \mathrm{cfu} / \mathrm{g}$ ).

Associations among some of the analyzed parameters and country regions were found. In fact, significant differences were found between LVT plus Alentejo and Algarve regarding potential pathogenic fungi $(p=0.010)$ and dermatophytes $(p=0.033)$. Each one of these parameters had higher counts in LVT and Alentejo regions. Significant differences $(p=0.004)$ were also found between North plus Central and Algarve in coliforms distribution, with North and Central having tenfold the counts of the Algarve.

Yeasts were detected in $25.4 \%$ of the sand samples (Table 2). Of the detected yeasts, $67.5 \%$ belonged to Candida species, with an average of $5.8 \mathrm{cfu} / \mathrm{g}$ (range 0-1934). A positive association was found between the presence of Candida and other yeasts $(p=0.00)$. Potential pathogenic fungi were found in $47.9 \%$ of the samples (Table 2). From those, Aspergillus sp. was the predominant genus, detected in 153 samples, with an average of $0.87 \mathrm{cfu} / \mathrm{g}$ (range 0250). In fact, a positive association was found between the presence of Aspergillus sp. and potential pathogenic fungi group $(p=0.000)$. Fusarium $s p$. was detected in 115 samples $(23.2 \%)$, followed by Scedosporium sp. (30 samples, 6.1\%), Scytalidium sp. (22 samples, 4.4\%), Chrysosporium sp. (17 samples, 3.4\%), and Scopulariosis sp. (13 samples, 2.6\%). Regarding dermatophytes, they were found in $14.3 \%$ of the analyzed samples and the most predominant genus was Trichophyton sp., detected in 69 sand samples, with an average of $1.5 \mathrm{cfu} / \mathrm{g}$ (range $0-152$ ) (Table 2). Microsporum sp. was detected in three samples $(0.61 \%)$ whereas no Epidermophyton isolates were recovered.

For bacteria (Table 2), intestinal enterococci were detected in 100 samples, followed by coliforms in 96 samples and E. coli, detected in 34 sand samples. Coliforms were, however, the bacteriological parameter with highest average of colony forming units per gram of sand (36.1). To assess possible relationships between the fungal and bacterial colonization of sands, data regarding total coliforms, E. coli, intestinal enterococci, and fungi were examined for 
correlations. A positive association was found between yeasts and coliforms $(p=0.005)$. All the other parameters did not show positive associations $(p>0.05)$.

Interesting positive associations were found among the analyzed fungi, namely between Aspergillus sp. and Chrysosporium sp. ( $p=0.00)$, Chrysosporium sp. and Fusarium sp. $(p=0.00)$, Fusarium sp. and Scytalidium sp. $(p=0.04)$, and also between Scopulariopsis sp. and dermatophytes $(p=0.00)$.

As there is no current values for health impacts of fungi and bacteria on beach sand, we herewith aim to propose thresholds values for the six parameters studied, based on the microbiological quality of sand beaches during the five years of study, considering that, as stated above, the batch of beaches used in this study is considered of good quality and hence meeting the blue flag award criteria (Associação Bandeira Azul da Europa, 2009). The threshold values we propose are the ones obtained when $95 \%$ of the samples analyzed are below those values. Thus, $15 \mathrm{cfu} / \mathrm{g}$ is the calculated threshold for yeasts, $17 \mathrm{cfu} / \mathrm{g}$ for potential pathogenic fungi, $8 \mathrm{cfu} / \mathrm{g}$ for dermatophytes and may serve as a national or regional references.

\section{Discussion}

Quality of life and the health of people is a complex function of different conditions in the living environment. Sand beaches may act as a passive element of cumulative pollution and can become contaminated by garbage, animal waste or water itself carrying pathogenic microorganisms and parasites (Sato et al., 2005). The microbiological context of sediments at the sediment-water interface in bathing waters is receiving increased attention (Arakel, 1995). There is evidence that faecal indicator and pathogenic bacteria survive for longer periods in sediments than in the overlying water and it has been proposed that sediments serve as sinks for fecal bacteria with the potential to pollute the overlying bathing waters (Ashbolt et al., 1993; Nix et al., 1993; Ghinsberg et al., 1994; Howell et al., 1996). Nevertheless, and despite the well established cause-effect relationship between faecal pollution of recreational waters and gastroenteritis outbreaks (Prüss et al., 1998), no epidemiological evidence of transmission between microbiological contamination of the sand and human infection has been found (World Health Organization, 2003). Persons with different immunological status are all beach users but immunossupressed individuals are more susceptible in acquiring infections caused by 
microorganisms that were found in sand beach (Burton et al., 1987; Mendes et al., 1993). Moreover, a recent epidemiological study published by Heaney et al., 2009, report that sand contact activities were associated with enteric illness at beach sites. Variation in beach-specific results suggests that site-specific factors may be important in the risk of illness following sand exposure.

This study provides original and comprehensive data on the microbiological content of sand along the Portuguese coast during a five year period. Our study was performed only in summer and using dry sand. Results of a study performed by Brandão et al., 2002 showed that microbiological contamination is higher in dry sand. Several other authors also showed that sand contamination during summer was higher than during spring and highest in dry sand (Mancini et al., 2005; Sato et al., 2005). A high proportion of the samples analyzed in our study showed zero or low colony-forming counts, for both fungi and bacteria. Nevertheless potentially harmful fungi and bacteria can be found in $66.5 \%$ of all the samples.

There is some evidence of a lower occurrence of microorganisms in areas with a hot and dry climate. In fact, Algarve was the region with the lowest 5 year, all beaches, average number of colony-forming units per gram of sand (62.5) when compared with beaches from the North and Central regions of the country (466.3 and 498.9 , respectively).

The potential health risk associated with the exposure to the contaminated sand should be higher in summer, especially for the people, usually children and youngsters, who tend to stay longer. Higher levels of bacteria in dry sand, that it is not under the influence of the tides, may indicate that the main source of faecal contamination is not the seawater, but instead the heavily polluted water of creeks and runoff (Vidal and Lucena, 1997; Sato et al., 2005). Our results showed that the first sampling period (prior to the bathing season) was the one with higher number of colony forming units of bacteria, decreasing along the summer season. This fact may be explained by the decrease of surface runoff and the increase of solar duration and intensity along the sampling periods. The presence of, higher levels of yeasts and dermatophytes in dry sand may indicate human contamination. Inversely to the trend for bacteria, the number of colony forming units increases from the first to the third sampling period. This may be explained by the increase of beach users in the third sampling period as well as by the higher resistance of fungi to solar exposure (Anderson et al., 2000). In fact, fungal spores 
can survive between 25 and 360 days in the environment whereas the survival of enteric bacteria on the surface of dry sand may be less. (Carillo-Muñoz et al., 1990; Papadakis et al., 1997). Thus, dry sand is the chosen matrix for fungi analysis whereas wet sand or water are better suited for quality assessment using enteric bacteria (Brandão et al., 2002),

The diversity of fungal species was high and $299(60.4 \%)$ of the samples were positive to species considered as potentially harmful, especially in immunocompromised persons. In fact, Lacaz, 1991, states that the variety of yeasts found in the soil and in seawater play an important role in the medical pathology, causing cutaneous mycosis. Candida species were found in $7.1 \%$ of samples whereas C. albicans was detected in only $0.8 \%$ of the samples. Absence or low incidence of $C$. albicans has also been recorded by other researchers (Roses Codinachs et al., 1988; Figueras et al., 1992). Sato et al., 2005 , on the contrary, obtained a higher value (17\%) in the 96 sand samples analyzed. These differences could be explained due to the fact that our samples are from beaches with good quality (with Blue Flag award) and probably also due to the discrepancy in the number of analyzed samples.

Potential pathogenic and allergenic fungi (like Aspergillus species) were the most common microorganisms found in our samples (in 30.9\%). The same situation was reported by Mendes 2 et al., 1998, also in Portuguese beaches, and by Sarquis and Oliveira (1996) and by Sharaf (2005) in Brazilian and Egyptian beaches, respectively.

Our samples revealed $14.3 \%$ of samples contaminated with dermatophytes. Studies performed by Sousa, 1990, also in the Portuguese central coastal area showed a much higher prevalence of dermatophytes (in $42 \%$ of the samples analyzed). In our study other filamentous fungi with keratinophilic activity were also found. In fact, Scytalidium sp., Chrysosporium sp. and Scopulariopsis sp. were isolated from $4.4 \%, 3.4 \%$ and $2.2 \%$ of the analyzed samples. Positive associations found among Chrysosporium sp., Fusarium sp., Scytalidium sp., Scopulariopsis sp. and dermatophytes could be explained by its keratinophilic nature. Keratinolytic fungi such as Chrysosporium sp. and Trichophyton,sp. are known as agents of human and animal infections and have been isolated from beach sand of European countries like Sweeden (Vidal et al., 1966), Spain (Ulfig et al., 1997) and Italy (Salvo and Fabianno, 2007), among others.

In our study, we found positive associations between coliforms and yeasts, and also between coliforms and E. coli. This association could be explained by possible sand contamination with 
surface runoff from surrounding areas polluted with organic material and human and animal waste. In an epidemiological study carried out on two beaches in Malaga, Spain, faecal index microorganisms were highly significantly correlated with dermatophyte fungi on one of the beaches and only E. coli showed a significant correlation with Candida albicans. At other studied beach, intestinal enterococci showed the best correlation with dermatophyte fungi (Borrego et al., 1991).

The current study provides a useful baseline for assessment of sand beach microbiological flora and as a warning to the occurrence of potentially harmful fungi and bacteria in these environments. Few studies have been performed to determine guideline values and in the absence of any specific guidelines based on epidemiological study, it is not possible to set firm limit levels. Preventive measures and health risk assessments have not been considered. This study with a high number of samples from Blue Flag beaches analyzed over a five year period will contribute towards establishing those values. Thus, for fungi, we propose $15 \mathrm{cfu} / \mathrm{g}$ for yeasts, $17 \mathrm{cfu} / \mathrm{g}$ for potential pathogenic fungi and $8 \mathrm{cfu} / \mathrm{g}$ for dermatophytes. The calculated threshold values for bacteria were much lower than the ones recommended for coastal bathing waters by Directive 2006/7/EC of the European Parliament and of the Council of 15 February 2006. Moreover, bacteria survive less time in dry sand than water. Thus, we recommend the adoption of the threshold limits for costal bathing waters $(<100 \mathrm{cfu} / 100 \mathrm{~mL}$ for intestinal enterococci and, $<250 \mathrm{cfu} / 100 \mathrm{mLfor} E$. coli). The derived thresholds merely set a result in a country wide context but do help in ranking sand beaches. Moreover, threshold limits have proved to be useful to alert beach managers to the danger of potential deterioration in beach quality.

\section{REFERENCES}

Abdallah, S.A., Elmanama, A.A., Fahd, M.I., Afifi, S, 2005. Microbiological Beach Sand Quality in the Gaza Strip in Comparison to Seawater. Polish Journal of Environmental Studies 14, 841850.

Alm, E.W., Burke, J., Spain A, 2003. Fecal indicator bacteria are abundant in wet sand at freshwater beaches. Water Research 37, 3978-3982. 
Anderson, J.G., Rowan, N.J., MacGregor, S.J., Fouracre, R.A., Farish O, 2000. Inactivation of Food-Borne Enteropathogenic Bacteria and Spoilage Fungi Using Pulsed-Light. IEEE Transactions on Plasma Science 28, 83-88.

Arakel, A.V, 1995. Towards developing sediment quality assessment guidelines for aquatic systems: an Australian perspective. Australian Journal of Earth Sciences 42, 335-369.

Ashbolt, N., Grohmann, G., Kueh C, 1993. Significance of specific bacterial pathogens in the assessment of polluted receiving waters of Sydney, Water Science Technology 27, 449-452.

Associação Bandeira Azul da Europa Guia, 2009. Interpretação dos Critérios Bandeira Azul para as Praias (http://www.abae.pt/4CF1E3B0-B929-4546-B78A1CF7A591D49E/FinalDownload/DownloadldDC0897632F38DDCA1906B3785DAAA506/4CF1E3B0-B929-4546-B78A1CF7A591D49E/programa/BA/docs/guia_zonas_balneares.pdf)

Borrego, J.J., Romero, P., Marino, F, 1991. Epidemiological study on bathers from selected beaches in Malaga. Athens, United Nations Environment Programme, Mediterranean Action Plan, pp. 1-27 (MAP Technical Reports Series No. 53).

Brandão, J.C., Veríssimo, C., Rosado, M.L., Sabino, R., Falcão, M.L., Giraldes, A., Rosado, C., Simões, M., Noronha, MG, 2002. Relatório final do projecto "Qualidade Microbiológica de areias de Praias Litorais". Associação Bandeira Azul da Europa.

Burton, J.R, Gunnison, D., Lanza, G.R, 1987. Survival of pathogenic bactéria in various freshwater sediments. Applied Environmental Microbiology 53, 633- 638.

Carillo-Muñoz, A.J., Torres-Rodriguez, J.M., Madrenys-Brunet, N., Dronda-Ayza, A, 1990. Comparative study on the survival of 5 species of dermatophytes and Scopulariopsis brevicaulis in beach sand under laboratory conditions. Revista Iberoamericana de Micologia 7, 36-38.

Figueras, M.J., Guarro, J., Soler, L., Inza, I., Polo F, 1992. Estudio piloto sobre la contamination de las playas del litoral Catalan. [A pilot study on the contamination of Catalounian beaches.] Proceedings of the $1^{\circ}$ Congreso Nacional del Medio Ambiente, Madrid.

Ghinsberg R.C., Leibowitz P., Witkin H., Mates A., Seinberg Y., Bar D.L., Nitzan Y., Rogol M, 1994. Monitoring of selected bacterial and fungi in sand and seawater along the Tel-Aviv Coast, MAP Tech Rep Ser 87, 65-81.

Gomes, D.N.F., Cavalcanti, M.A.Q., Fernandes, M.J.S., Lima, D.M.M., Passavante, J.Z.O, 2008. Filamentous fungi isolated from sand and water of "Bairro Novo" and "Casa Caiada" beaches, Olinda, Pernambuco, Brazil. Brazilian Journal of Biology 68, 577-582.

Heaney, C.D., Sams, E., Wing, S., Marshall ,S., Brenner, K., Dufour, A.P., Wade, T.J, 2009. Contact With Beach Sand and Risk of Illness. American Jounal of Epidemiology 170, 164-172.

Howell J.M., Coyne M.S., Cornelius P.L, 1996. Effect of sediment particle size and temperature on fecal bacteria mortality rates and the fecal coliform/fecal streptococci ratio. Journal of Environmental Quality 25, 1216-1220.

Lacaz, C.S., 1991. Micologia Médica., $1^{\text {st }}$ ed. Savier, São Paulo.

LaLiberte, P., Grimes D, 1982. Survival of Escherichia coli in Lake bottom sediments, Applied Environmental Microbiology 43, 623-628.

Mancini, L., D’Angelo, A.M., Pierdominici, E., Ferrari, C., Anselmo, A., Venturi, L., Fazzo, L., Formichetti, P., laconelli, M., Pennelli, B, 2005. Microbiological quality of Italian beach sands. Microchemical Journal 79, 257-261. 
Matavulj, M., Vulikiã, N., Gojkoviã, I., Karaman, M, 2005. Conditionally pathogenic fungi in recreational waters. Proc Nat Sci Matica Srpska Novi Sad 109, 149-160.

Mendes, B., Nascimento, M.J., Oliveira, J.S, 1993. Preliminary characterisation and proposal of microbiological quality standard for sand beaches. Water Science Technology 27, 453-456.

Mendes, B., Urbano, P., Alves, C., Morais, J., Lapa, N., Oliveira, J. S, 1998. Fungi as environmental microbiological indicators. Science Technology 38, 155-162.

Nix, P.G., Daykin, M.M., Vilkas, K.L, 1993. Sediment bags as an integrator of fecal contamination in aquatic systems, Water Research 27, 1569-1576.

Obiri-Danso, K., Jones, K, 2000. Intertidal sediments as reservoirs for hippurate negative Campylobacters, Salmonellae and Fecal Indicators in three recognized bathing waters in North West England, Water Research 34, 519-527.

Papadakis, J.A., Mavridou, A., Richardson, S.C., Lambiri, M., Marcelou, U, 1997. Bather related microbial and yeast populations in sand and seawater. Water Research 31, 799-804.

Prado, B., Bernal, P., Contreras, M., Savedra, M., Del Moral, A., Joyas, M, 1994. Numerical taxonomy of staphylococci isolated from water and beach sand from Valparaíso and viña del Mar, Chile. Revista Iberoamericana Microbiologia 36, 71-77.

Prüss, A, 1998. A review of epidemiological studies from exposure to recreational waters. Int Journal of Epidemiology 27, 1-9.

Roses Codinachs, M., Isern Vins, AM., Ferrer Escobar, M.D., Fernandez Perez, F, 1988. Microbiological contamination of the sand from the Barcelona city beaches. Revista de Sanidad e Higiene Publica 62, 1537-1544.

Salvo, V.-S., Fabiano, M, 2007. Mycological assessment of sediments in Ligurian beaches in the Northwestern Mediterranean: Pathogens and opportunistic pathogens. Journal of Environmental Management 83, 365-369.

Sarquis, M.I.M., Oliveira, P.C, 1996. Diversity of microfungi in the sandy soil of Ipanema Beach, Rio de Janeiro, Brazil. Journal Basic Microbiology 36, 51-58.

Sato, M.I.Z., Di Bari, M., Lamparelli, C.C., Cristina, T.A., Coelho, M.C.L.S., Hachich, E.M, 2005. Sanitary quality of sands from marine recreational beaches of São Paulo, Brazil. Brazilian Journal of Microbiology 36, 321-326.

Sharaf, E.F, 2005. A potent chitinolytic activity of Alternaria alternata isolated from Egyptian black sand. Polish Journal of Microbioly 54,145-151.

Sousa, M.L.R, 1990. Micoses. Lisbon, National Institute of Health (INSA), Centre of Epidemiologic Surveillance of Transmissible Diseases (Epidemiology Bulletin No. 5).

Ulfig, K., Guarro, J., Cano, J., Gene, J., Vidal, P., Figueras, M.J, 1997. General Assessment of the occurrence of keratinolytic fungi in river and marine beach sediments of Catalonian waters (Spain), Water Air and Soil Pollution 94, 275-287.

Vidal, J., Lucena, F,1997. Effect of the rains on microbiological quality of bathing waters in Mediterranean areas. Technical feasibility of an a priori measurement approach for managing bathing water quality. Report of the Workshop Held in Sitges (Spain) on April, 26-29.

Vidal, P., Sanchez-Puelles, J.M., Milan, D., Guarro, J, 1966. Chrysosporium on the west coast of Sweden. Acta Dermatology-Venereologica 46, 78-81. 
Vieira, R. H. S. F., Rodrigues ,D. P., Menezes, E.A., Evangelista, N. S. S., Reis, E.M.F., Barreto, L. M., Gonçalves, F. A, 2001. Microbial contamination of sand from major beaches in fortaleza, ceará state, Brazil. Brazilian Journal of Microbioly 32, 77-80.

Whitman, R.L., Nevers, M.B., Byappanahalli, M.N, 2006. Examination of the watershed-wide distribution of Escherichia coli along southern Lake Michigan: an integrated approach. Applied Environmental Microbiology 72, 7301-7310.

World Health Organization. 2003. Guidelines for safe recreational water environments. Volume 1, Coastal and fresh waters. World Health Organization, Geneva.

\section{DECLARATION OF INTEREST}

The authors report no conflicts of interest. The authors alone are responsible for the content and writing of the paper.

\section{AUTHORS' CONTRIBUTIONS}

CV, LF, LR, JB conceived and designed the study. RS, FCF, MAC, BW, RR, HP, CV, CP, and JB performed the experiments; RS, CV, LF, LR, EP, JB analyzed the data, EP being the statistician; RS, CV, LF, JB wrote the manuscript. All authors have read and approved the final version of the manuscript.

\section{ACKNOWLEDGEMENTS}

We are indebted to Andrew Wither for kindly reviewing the manuscript. 
Fig.1. Collection points along the Portuguese coast.

Fig. 2 Microbiological quantification of bacteria (a) and fungi (b) along three sampling periods (1st -June, 2nd -July,3rd August). 
Table 1. Microbiological parameters analyzed in sand samples.

\begin{tabular}{|c|c|c|c|}
\hline \multicolumn{3}{|c|}{ Mycological parameters } & \multirow[b]{2}{*}{$\begin{array}{c}\text { Bacteriologica } \\
\text { parameters }\end{array}$} \\
\hline Yeasts & $\begin{array}{c}\text { Potential } \\
\text { pathogenic/allergogenic } \\
\text { moulds }\end{array}$ & Dermatophytes & \\
\hline Candida albicans & Aspergillus fumigatus & Trichophyton sp & Coliforms \\
\hline Candida sp (Other species) & Aspergillus niger & Microsporum sp & \\
\hline Cryptococcus neoformans & Aspergillus sp (Other species) & Epidermophyton sp & Escherichia coli \\
\hline \multirow[t]{6}{*}{ Other yeasts } & Chrysosporium sp & & \\
\hline & Fusarium sp & & Intestinal enterococci \\
\hline & Scytalidium sp & & \\
\hline & Scedosporium $s p$ & & \\
\hline & Scopulariopsis sp & & \\
\hline & Others & & \\
\hline
\end{tabular}

Table 2. Microbiological characterization of the analyzed sand samples during the five years of study.

\begin{tabular}{ccccccc} 
& Negative & $\begin{array}{c}\text { Positive to } \\
\text { fungi }\end{array}$ & $\begin{array}{c}\text { Positive to } \\
\text { bacteria }\end{array}$ & $\begin{array}{c}\text { Positive to bacteria } \\
\text { and fungi }\end{array}$ & $\begin{array}{c}\text { Positive only to } \\
\text { fungi }\end{array}$ & $\begin{array}{c}\text { Positive only } \\
\text { to bacteria }\end{array}$ \\
\hline $\mathbf{2 0 0 6}$ & 35 & 61 & 21 & 18 & 44 & 3 \\
$\mathbf{2 0 0 7}$ & 28 & 64 & 27 & 24 & 44 & 3 \\
$\mathbf{2 0 0 8}$ & 29 & 63 & 32 & 25 & 30 & 7 \\
$\mathbf{2 0 0 9}$ & 31 & 63 & 18 & 13 & 50 & 5 \\
$\mathbf{2 0 1 0}$ & 43 & 48 & 27 & 20 & 36 & 6 \\
Total & $\mathbf{1 6 6}$ & $\mathbf{2 9 9}$ & $\mathbf{1 2 5}$ & $\mathbf{1 0 0}$ & $\mathbf{2 0 4}$ & $\mathbf{2 4}$ \\
\hline
\end{tabular}

Table 3. Mycological and bacteriological parameters analyzed in the 495 sand samples

\begin{tabular}{lcc} 
& No. of positive samples (\%) & cfu/g average per sample (range) \\
\hline Yeasts & $126(25.4)$ & $8.7(0-1997)$ \\
Potential pathogenic fungi & $237(47.9)$ & $4.5(0-267)$ \\
Dermatophytes & $71(15.3)$ & $1.7(0-152)$ \\
Coliforms & $96(19.4)$ & $36.1(0-2420)$ \\
E. coli & $34(6.9)$ & $11.8(0-2420)$ \\
Intestinal enterococci & $100(20.2)$ & $10.1(0-2420)$ \\
\hline
\end{tabular}

Legend: cfu/g - colony forming units per gram of sand 


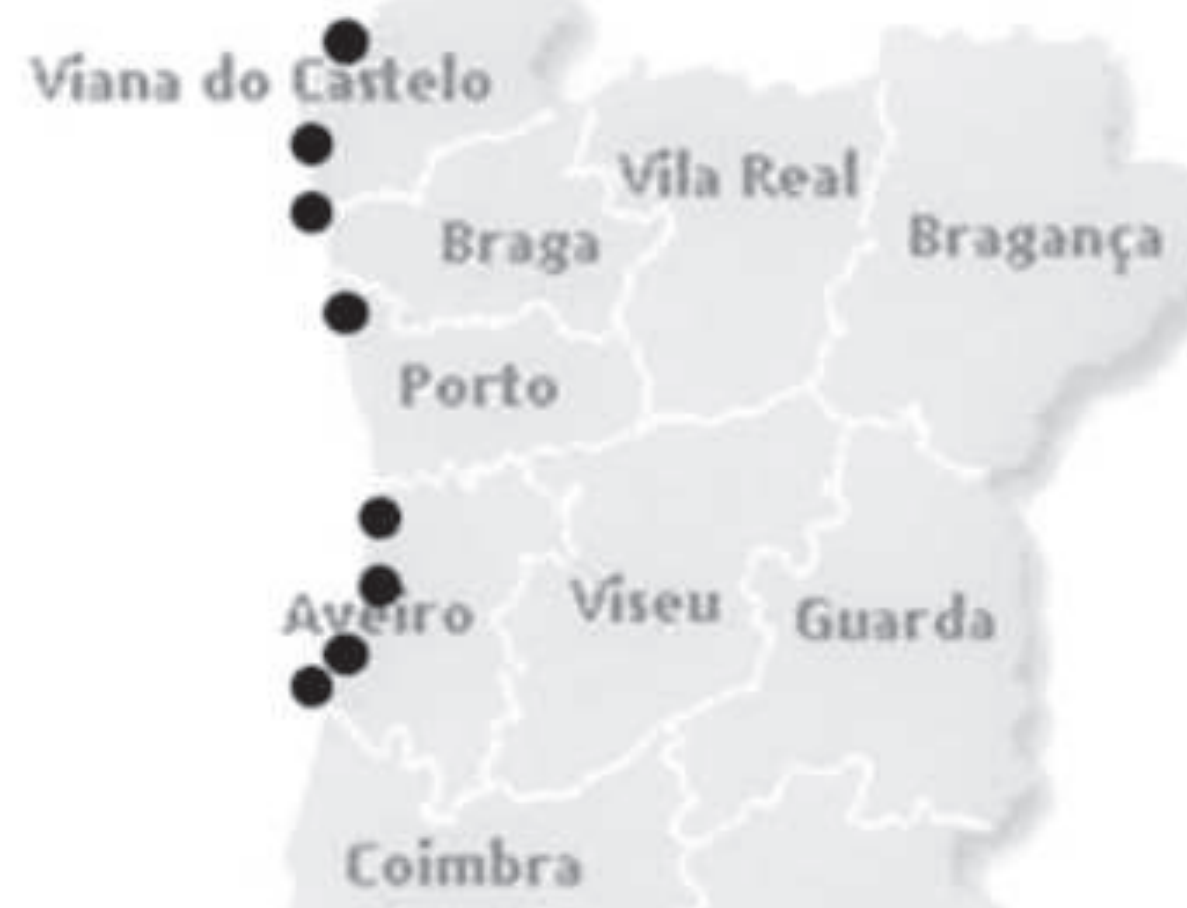

\section{Castelo Branco}

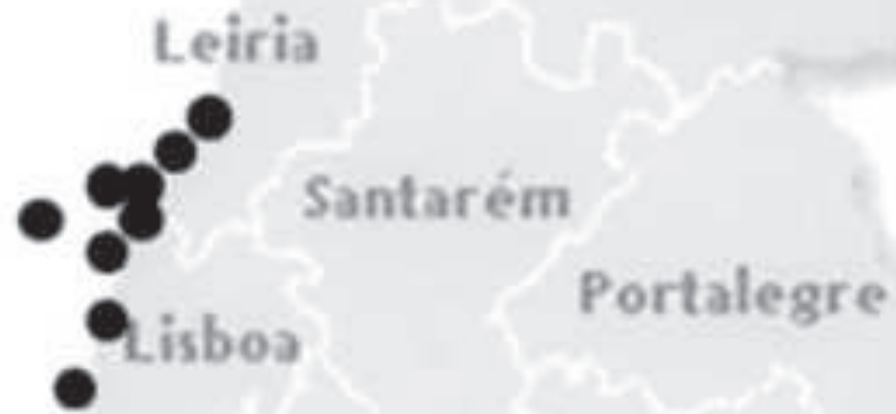

\section{Evora}

\section{Setúbal}

Beja

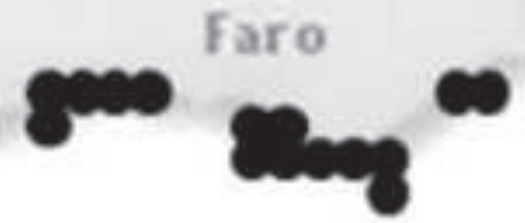




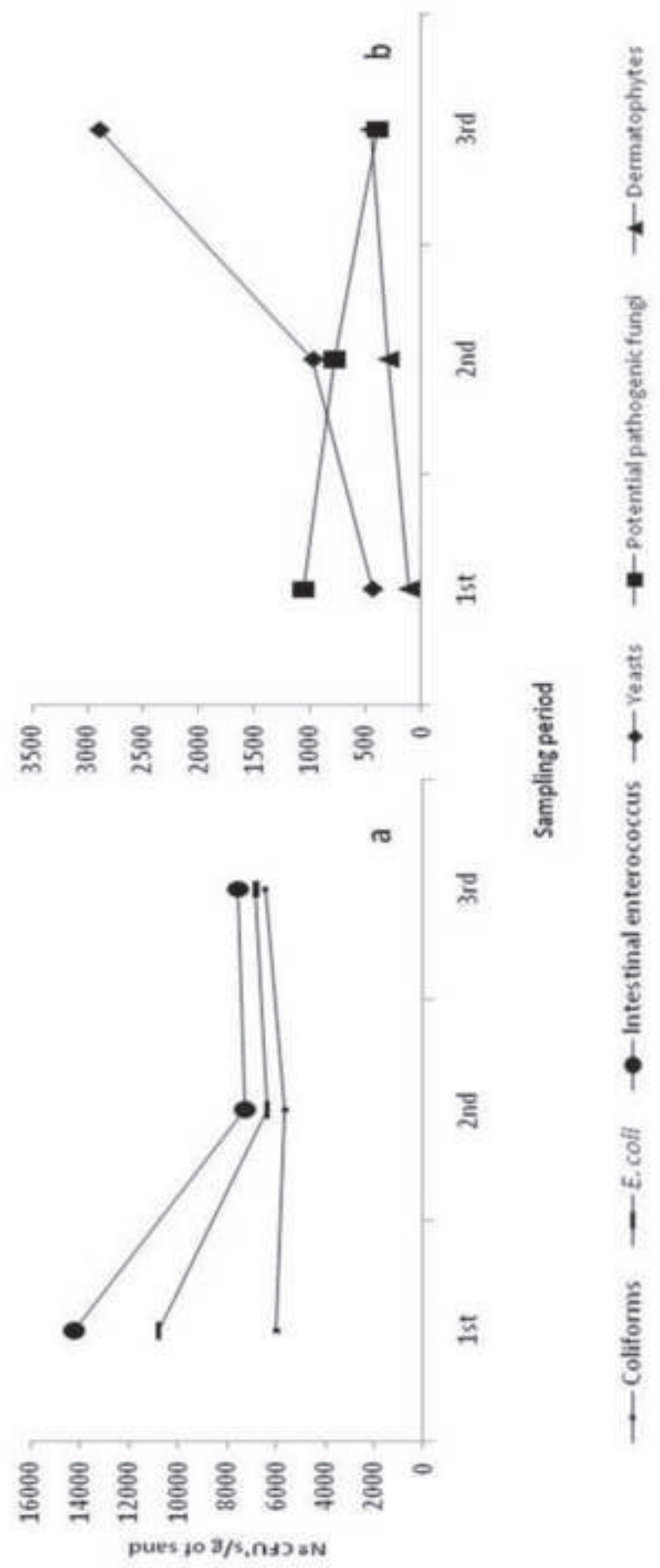

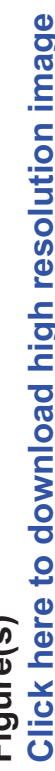

